\title{
Training in diabetes education: meanings attributed by primary care nurses
}

\author{
Formação em educação em diabetes: significados atribuídos por enfermeiros da atenção primária \\ Formación en educación en diabetes: significados atribuidos por enfermeros de atención primaria
}

\section{Magda Coeli Vitorino Sales Coêlho', Camila Aparecida Pinheiro Landim Almeida', Ana Roberta Vilarouca da Silva", Luana Kelle Batista Moura', Lucíola Galvão Gondim Corrêa Feitosa', Laura Barbosa Nunes ${ }^{\text {III }}$}

\author{
' Centro Universitário Uninovafapi. Teresina, Piauí, Brazil. \\ "Universidade Federal do Piauí, Department of Nursing. Teresina, Piauí, Brazil. \\ I" Universidade Federal de Minas Gerais. Belo Horizonte, Minas Gerais, Brazil.
}

How to cite this article:

Coêlho MCVS, Almeida CAPL, Silva ARV, Moura LKB , Feitosa LGGC, Nunes LB. Training in diabetes education: meanings attributed by primary care nurses. Rev Bras Enferm [Internet]. 2018;71(Suppl 4):1611-8. [Thematic Issue:

Education and teaching in Nursing] DOI: http://dx.doi.org/10.1590/0034-7167-2017-0792

Submission: 11-10-2017 Approval: 12-27-2017

\section{ABSTRACT}

Objective: seize meanings attributed by primary care nurses to training in diabetes education. Method: exploratory and descriptive study, with a qualitative approach, with twenty primary care nurses; semistructured interview script, with interviews processed in the IRaMuTeQ software and analyzed through the Descending Hierarchical Classification. The results were subsidized in the Representational Theory of Meaning. Results: nurse training in diabetes education is insufficient for holistic action, although it allows the community to be instrumentalized in specific issues about the disease, using the limited tools available, especially lectures. Nurses find themselves in a context of challenges, improvisations, weaknesses, and limitations that determine the meaning attributed to diabetes education and subsequent actions. Conclusion: the meanings attributed by the nurses revealed an incipient training, which limits the quality of care provided and instigates the search for qualification.

Descriptors: Higher Education; Nursing; Primary Health Care; Diabetes Mellitus; Health Education.

\section{RESUMO}

Objetivo: apreender significados atribuídos por enfermeiros da atenção primária à formação em educação em diabetes. Método: estudo exploratório e descritivo, de abordagem qualitativa, com vinte enfermeiros da atenção primária; roteiro semiestruturado de entrevista, com depoimentos processados no software IRaMuTeQ e analisados por meio da Classificação Hierárquica Descendente. Os resultados foram subsidiados na Teoria Representacional do Significado. Resultados: a formação do enfermeiro na educação em diabetes é insuficiente para atuação holística, embora permita instrumentalizar a comunidade em questões pontuais acerca da doença, utilizando-se das limitadas ferramentas disponíveis, sobretudo palestras. Os enfermeiros se veem num contexto de desafios, improvisações, fragilidades e limitações, determinantes para o significado atribuído à educação em diabetes e para ações subsequentes. Conclusão: os significados atribuídos pelos enfermeiros revelaram uma formação incipiente, o que limita a qualidade da assistência prestada e instiga a busca pela qualificação.

Descritores: Educação Superior; Enfermagem; Atenção Primária à Saúde; Diabetes Mellitus; Educação em Saúde.

\section{RESUMEN}

Objetivo: aprehender significados atribuidos por enfermeros de atención primaria a la formación en educación en diabetes. Método: estudio exploratorio y descriptivo, de abordaje cualitativo, con veinte enfermeros de atención primaria; guía semi-estructurado de entrevista con testimonios procesados en el software IRaMuTeQ y analizados por medio de la Clasificación Descendente Jerárquica. Los resultados fueron subsidiados en la Teoría Representacional de Significado. Resultados: la formación del enfermero en la educación en diabetes es insuficiente para la actuación holística, aunque permita instrumentalizar a la comunidad en cuestiones puntuales sobre la enfermedad, utilizando las limitadas herramientas disponibles, sobre todo las conferencias. Los enfermeros se ven 
en un contexto de desafíos, improvisaciones, fragilidades y limitaciones, determinantes para el significado atribuido a la educación en diabetes y para acciones subsiguientes. Conclusión: los significados atribuidos por los enfermeros revelaron una formación incipiente, lo que limita la calidad de la asistencia prestada e instiga la búsqueda por calificación.

Descriptores: Educación Superior; Enfermería; Atención Primaria de Salud; Diabetes Mellitus; Educación en Salud.

CORRESPONDING AUTHOR Magda Coeli Vitorino Sales CoêlhoＥ-mail: magdacoeli@uninovafapi.edu.br

\section{INTRODUCTION}

Longevity, sedentary lifestyle and obesity contribute to the increased chronic noncommunicable diseases. Among them, diabetes mellitus $(\mathrm{DM})^{(1)}$, a multifactorial condition characterized by persistent hyperglycemia, which causes long-term micro and macrovascular complications ${ }^{(2-4)}$. Considered an epidemic because it is present with a high incidence in all continents, it is also a public health problem due to social damages and costs related to treatment, in addition to the high morbimortality ${ }^{(2-3)}$.

In this sense, although DM treatment is based on pharmacological interventions, the importance of non-pharmacological strategies in the good prognosis of the disease, which mainly involve regular behavioral compliance, is highlighted. Treatment depends directly on the person, although it indirectly involves family support and sufficient health resources for such a demand. Multiprofessional follow-up occurs due to the need for glycemic control and the prevention of complications. Therefore, the involvement of the person living with DM and the follow-up team becomes essential, so that together they develop selfmanagement strategies and achieve control of the disease $\mathrm{e}^{(4)}$.

Brazil's Unified Health System (SUS) ensures a multiprofessional follow-up to the person with DM through the Family Health team (eSF) at the primary care level. In this process, multiprofessional support must develop conditions for the individual to acquire autonomy over their care, to be able to understand, evaluate and make decisions about DM. In this way, diabetes education is the most effective strategy for achieving autonomy, making it indispensable to reach a good standard of self-care ${ }^{(5-6)}$.

The nurse is a member of the eSF and has several attributions in the follow-up of the person with DM ranging from prevention and screening to the intensification of glycemic control, educational activities ${ }^{(5)}$. It is recommended that this professional has technical and scientific skills and competences to adequately manage DM treatment and exercise his/her role as a health educator $^{(6)}$. To do so, their training should provide skills and competences to act in a generalist way, however with an aptitude for managing the chronic condition, with a vision for integrality of care, in an equitable and universal way ${ }^{(7)}$.

However, in the literature, especially in Latin America, there are gaps in the evaluation of training in diabetes education for professionals working in primary care, especially nurses, since the studies are focused on the on pathophysiological aspects of the disease.

\section{OBJECTIVE}

Seize meanings attributed by primary care nurses to training in diabetes education.

\section{METHOD}

\section{Ethical aspects}

The study complied with all ethical precepts of the current research resolution (No. 466/12), and it was submitted and approved by the Research Ethics Committee of the Centro Universitário Uninovafapi. It was sought to preserve the conditions of anonymity and confidentiality of the contents declared by coding the files using the letter " $E$ ", which represented "nurse", followed by an Arabic number from 1 to 20 , sequential to the interview.

\section{Type of study}

It was an exploratory study, with a qualitative approach.

\section{Theoretical and methodological background}

For this research, we rely on Ogden and Richards' Representational Theory of Meaning (RTM), which states that words are instruments that do not mean anything by themselves; it is only when a thinker uses them is that they represent something, that is, they have meaning. This theory refers to the belief that meaning has many concepts, adopting the one that presents the representational sense $\mathrm{e}^{(8-10)}$.

To facilitate the understanding of the nature of the symbol sign, the authors developed the "triangle of meaning", a model that brings the interconnection of three elements to the development of the meaning sense: the symbol (what does the word mean?), the relative (what is the meaning of this thing?) and the person or the thought (what does that mean to you?)(10). The symbol raises in the person an image of a wider context in which the sign was originally perceived.

\section{Participants, place, and sample}

The data collection was conducted through a semistructured script, applied through the technique of comprehensive interview, with twenty nurses who work in the eSF of a capital of Northeast Brazil. Professionals who worked for more than one year were enrolled in the Basic Health Unit (UBS) visited. Professionals who were in a substitution regime were excluded because of the transitional situation that unties the professional from the personal and social reality of the person being assisted, which constitutes a bottleneck for obtaining the personal longitudinality in eSF.

The number of participants in the study was determined by their representativeness and the depth of the meanings expressed by the interviewees, with the collection being interrupted by the homogeneity of the information, making it possible to meet the objectives of the study and to respond to the researchers' concerns. Initially to select the participants were drawn by the application Random, fifty of the 92 existing UBS, which would be visited to interview one participant. However, 25 were visited, and in five of them the nurse was excluded. 


\section{Data collection and organization}

To present the study, a prior telephone contact, invitation, and appointment scheduling were performed according to the participant's availability. Data were collected between January and March 2017, in a private environment of the UBS and individually. The dialogues were conducted in a free way by one of the researchers who was properly trained. The interviews were recorded and had an average duration of 35 minutes, totaling more than seven hours of dialogue. At the end, the participants were given the opportunity to listen to their reports, and they were asked about the desire to leave the study or to change any speech; there were no withdrawals or changes. The speeches were transcribed fully and returned to the participants for validation after transcription.

\section{Data analysis}

The software IRaMuTeQ (acronym for Interface de R pour les Analyses Multidimensionnelles de Textes et de Questionnaires) for data processing ${ }^{(11)}$. It was decided to use a software in this step due to the increase of this resource in qualitative approach studies in recent years, mainly due to the transparency and systematic granted to the process in that case ${ }^{(12-13)}$. Nevertheless, it should be noted that its use is not configured in a data analysis method, but in an auxiliary processor tool, with interpretation and naming of classes intended to the researcher(13-16).

The data were treated by the Descending Hierarchical Classification (DHC) method, according to previous studies ${ }^{(13-16)}$. In this method, the textual corpus (interviews) is classified according to its vocabularies, and their set is divided by the frequency of the reduced forms, in order to obtain a stable and definitive classification from repeated $X^{2}$ tests. The discussion of the DHC findings, along with the interviews related to each class obtained, was subsidized in the RTM.

\section{RESULTS}

The participants were twenty nurses from eSF, and nineteen females, with a mean age of 45 years, mean time of professional activity of fourteen years and training time between five and twenty years. On the completion of post-graduations, they all revealed the completion of specializations (lato sensu), and five had completed the master's degree. With regard to training in diabetes education, eight nurses reported having performed it.
Regarding the interviews, IRaMuTeQ recognized the separation of the corpus in 133 Elementary Context Units (ECU) from 168 text segments. There were 5885 occurrences, with a usefulness of $79.17 \%$ of the total textual corpus. DHC allowed to identify and analyze the textual domains, in addition to interpreting the meanings attributed by the participants, naming their respective meanings in six classes originating from three axes.

During division, the first axis formed originated in class 1 , related to the meanings of diabetes education. This axis has two branches, represented by classes 2 and 3, which address diabetes education. Class 4 emerged from the second corpus partition, with content depicting the strategies of diabetes education for the user and the meanings of nurse practice. The third axis comprises classes 5 and 6 , related to diabetes mellitus control tools and to the meanings and challenges of diabetes education, respectively (Figure 1).

\section{The classes and their meanings}

In class 1, titled "Meaning of diabetes education," participants attribute concepts to diabetes education mostly based on their perception and experience as professionals. In addition, they recognize the importance of this training for the quality of life of the person living with DM. However, there is still a strong tendency towards the biomedical model of professional performance, which focuses on healing actions in detriment of comprehensive care strategies.

The transmissionist practice (unidirectional transmission of messages) as a predominant methodology in the process of educating for DM is noteworthy. The relation of power of knowledge between the professional and the user puts the user in the position of "compliant", as it can be observed in the predominance of the words or symbols "to guide", "to raise awareness", "to dominate" knowledge. Such attitudes are controversial since the ultimate goal is to build concepts, to encourage a lifestyle change and to promote empowerment over self-care.

It is the inheritance of a banking education, that is, based on the simple deposit of knowledge in the student. In this perspective, it is up to the student to comply with the determinations imposed by the professional, who dominates the knowledge characteristic of the care centered on the disease.

It is to guide the patient about the importance of being able to control and understand what diabetes is. (E2)

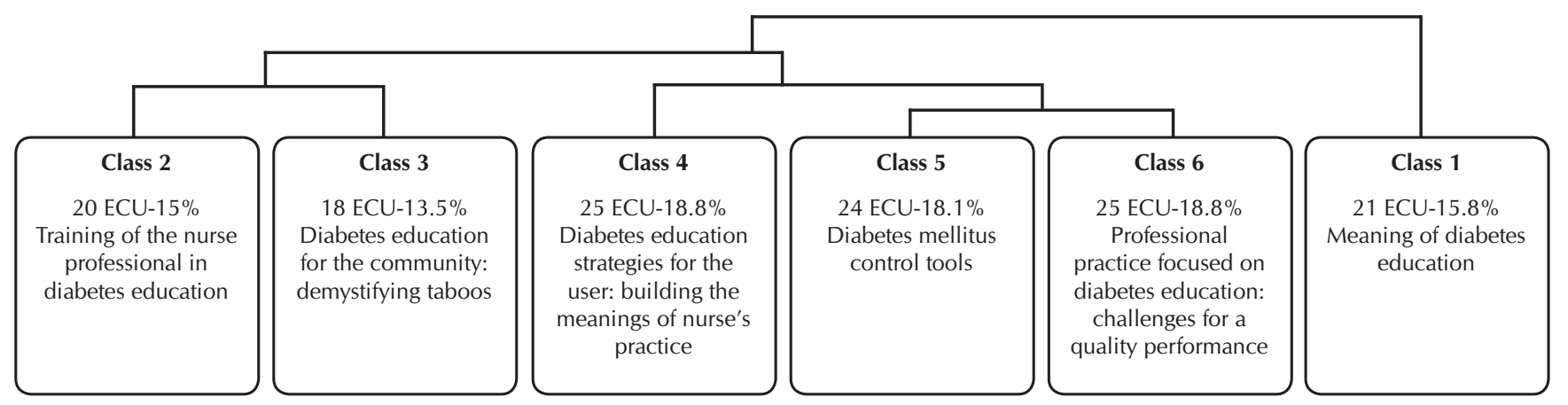

Note: ECU: Elementary Context Unit.

Figure 1 - Thematic structure of the meanings attributed by primary care nurses to training in diabetes education 
To have knowledge about the pathology, management of the treatment and prevention, to awaken in the patient the need for self-care. (E5)

It means to provide correct and accessible guidelines for self-care. (E6)

It consists of raising awareness about the disease, forms of prevention and self-control, thus avoiding possible complications. (E8)

It means being informed about the pathology its complication [...] fundamental importance for the quality of life of the person who has the disease minimizing its complications. (E10)

In class 2, called "Training of the nurse professional in diabetes education", participants stated that training is a dynamic process, started at the undergraduate level and modified according to the requirements of professional activities. The qualitative analysis of the most evoked vocabulary evidences the incipience of the knowledge acquired in the undergraduate level, as well as the search for "new" useful knowledge to act in a qualified way in diabetes education.

At the undergraduate level, I had a slight introduction we see it very little. (E13)

The nurses in their basic training have very little knowledge about the subject [...], we often need to resort to other training and information to feel secure to work with this audience. (E16)

Updates that we always do, there is also the issue of drugs and news that are appearing that is being updated. (E20)

Class 3 is entitled "Diabetes education for the community: demystifying taboos". Its content is focused on the role of the nurse educator and the concern of this professional in socializing DM prevention measures. In this class, the participants still recognize the need for family involvement in the process of caring for the person living with DM, identifying the relevance of the demystification of taboos related to the condition, preventive measures, risk factors, treatment and life habits.

Every day I do health education with all the patients I serve in order to prevent diabetes from developing [...] I do daily prevention. (E9)

We have a big focus on the chronic diseases that mostly affect [the community], especially the elderly. (E11)

and even demystify with the family that this is not the end of life. [...] someone in the family because he or she will not always have a close healthcare provider to administer this drug [...] it is extremely important since it is a pathology it is a disease that affects a large number of people [...] and the trend is to have more and more patients with diabetes. (E16)

Because they have their taboos because there are a lot of people that inform them wrongly. (E18)
Class 4 revealed "Diabetes education strategies for the user: building the meanings of nurse's practice". The contents seized in this class referred to the strategies used to perform diabetes education, focused mainly on the lecture and the nursing consultation. On the other hand, they showed the concern of the participants in implementing actions to improve patients' compliance to follow-up, with drug assurance, return and active search for those who miss.

I cannot have a more systematic follow-up. (E4)

Unfortunately, we end up having to do it inside the office. (E15)

The strategies of lectures, because we have the HIPERDIA group it performs the blood glucose and delivers the drug for thirty days to have the return and it also performs the active search too in case they do not come. (E18)

I take advantage of the individual care that is the moment that I can have this face to face with the patient and provide these guidelines to them. (E19)

From class 5 emerged the "DM control tools", which are: guidelines on the use of the drug, food and glycemic control, in addition to performing the exams and foot care. Although correct, these guidelines are still punctual and disjointed, showing weaknesses in the training of the participants, who do not fully develop the steps of education, mainly because they do not know the basic elements involved in the clinical management of the person living with DM, such as: systematic selfmonitoring; glycemic targets and $\mathrm{HbA} 1 \mathrm{c}$ levels; weight and stress management; stimulation to the practice of physical activity; recognition of complications; and decision-making in the face of glycemic decompensation.

What that drug means for them, the importance of taking [the drug] at the correct time [...] the use of insulin therapy, administering insulin, avoiding certain foods and replacing with others, working a lifestyle change. (E16)

Advising how to make glucose, how to make insulin, to eat, to do the self-examination of the feet. (E15)

Daily routine guidelines regarding foot care. (E4)

Finally, in class 6, entitled "Professional practice focused on diabetes education: challenges for a quality performance", the participants revealed their weaknesses and limitations when they recognize the specificity necessary to care for those living with DM. The difficulties related to social issues and the lack of investments in continuing education compromise the skills and abilities in assisting the person living with DM in primary care.

It is a very specific group it is complicated to evaluate so the practice I think it should be better. [...] it is difficult, we have a little difficulty because we do not have a follow-up. (E4)

I think it contributes to the better quality of life of the bearer, but at other times I get no response. (E14) 
In training we had only a generalist view of the diabetic today we have a daily need that makes us seek new knowledge we have the need of the institutions to invest better in the training of professionals for diabetes education. (E17)

Thus, through DHC (distribution of classes and their contents), it can be seen that the training of nurses focused on diabetes education is insufficient for holistic action, although it makes it possible to instrumentalize the community in specific issues about the disease, especially taboos. For this, the nurse uses certain tools, especially lectures, that are within their reach at this level of health care surrounded by challenges. Therefore, this context of challenges, improvisations, weaknesses, and limitations that surround nurses' practice in primary care is determinant for the meaning attributed to diabetes education and for subsequent actions.

\section{The meanings in the thought and relative}

The symbols represented by the ECUs were used to construct the meanings or thoughts unveiled by the classes of words evoked in the textual corpus (Figure 2).

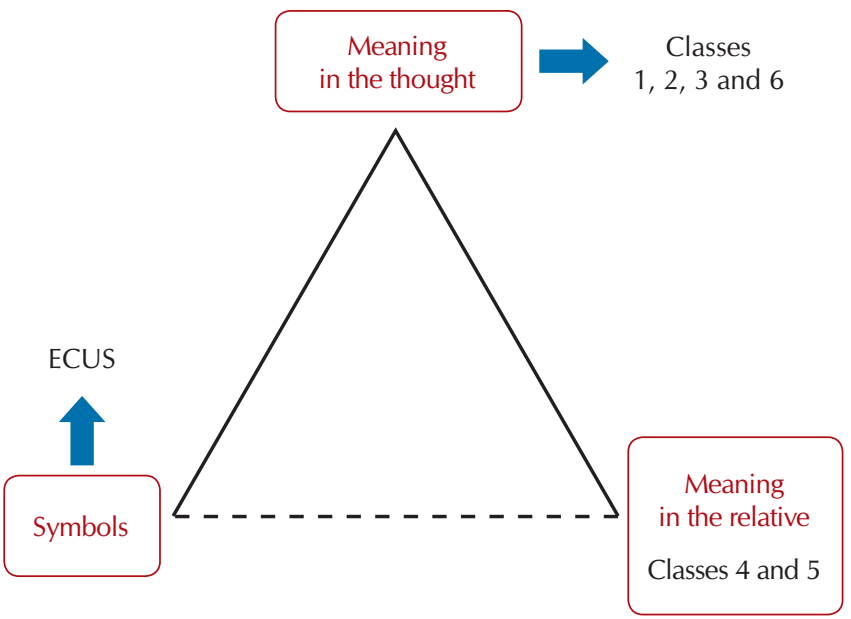

Note: ECUs - Elementary Context Units

Figure 2 - Triangle of meanings attributed by nurses to practice and training in diabetes education, Teresina, Piauí, Brazil, 2017

The meanings of the training were built based on the internalization of contents and experiences experienced during the professional activity, subsidized in the small previous training in diabetes education. The verbalization of these contents and experiences becomes the meanings in the relative within the universe of the nurses interviewed. Thus, the structuring of the six classes based on the evoked symbols allowed us to seize the meanings attributed by nurses to diabetes education and to understand their reality.

\section{DISCUSSION}

Nurses in primary health care characterize their training for diabetes education as insufficient to meet the demand. The practice is still based on a biomedical model of healing, the education process uses transmission methods and it has few tools for its instrumentalization.

The literature provides evidence that the participation of people with type $2 \mathrm{DM}$ in educational programs reduces $\mathrm{HbA} 1 \mathrm{c}$ levels and it improves metabolic control, as well as it stimulates changes in lifestyle $\mathrm{e}^{(17-18)}$. Therefore, educational self-management interventions are necessary, since they revealed significant improvements in $\mathrm{HbA} 1 \mathrm{c}$, self-efficacy, and knowledge about DM, which justifies the relevance of investing in educational practices as a complement to the therapy, as pointed out by the nurses in this study. It is also an opportunity for enlightenment that requires interaction between the professional and the person with DM, with the aim of awakening the critical-reflexive potential in both, streamlining the process of teaching ${ }^{(19)}$.

Diabetes education helps the person with DM identify possible solutions to the obstacles that prevent them from complying with multiprofessional treatment and recommendations. Therefore, it cannot be achieved by a mere unilateral transmission of information ${ }^{(20-21)}$.

The nurses of this study revealed a practice centered on the biomedical model, based on the transmissionist method of providing guidelines and imposing conditions, especially when one observes the construction of the relative on diabetes education. The nurse is expected, for being acknowledged as a health educator, to play a mediating role, becoming more sensitive to the demands of the user. With this, the relationships gain more holistic nuances, considering the experiences to structure the treatment and favoring the shared decision-making about the treatment, from the exchange of information that integrates the scientific evidence in the care centered in the person with $\mathrm{DM}^{(21)}$.

However, the roots of the training centered in the individual/ disease/healing triad are denounced when the participants highlight the meaning of an incipient training in the field of diabetes education, a previous training that does not allow them to construct an educational practice focused on self-management of care. The technicist model of educating does not stimulate the epistemology of care practice ${ }^{(22)}$ and, in addition, the labor market requires general practitioners to work at all levels of healthcare and to meet social demands. On the other hand, care practice requires nurses with technical-scientific skills and competences to develop aptitudes in the patient to manage their condition in their social context ${ }^{(20)}$.

By recognizing that training in diabetes education is not sufficient for holistic care, professionals confirm the gaps between the contents of curricular guidelines and reveal the distance between theory and practice, identifying these factors as challenges to be faced ${ }^{(7)}$. The training gaps significantly affect the nurses' idea of their capacity to act, mainly due to the superficiality of the approach of technical and managerial procedures and skills in the context of diabetes education, making the practice a simple repetition of recommended actions ${ }^{(22)}$.

However, the training process is not limited to university education, as pointed out by the participants. Continuing education emerges in this context as "learning at work", dynamic, accompanying professional maturation and it requires individual and institutional investments to meet the needs of the labor market once the processes of learning and teaching are incorporated into the daily life of the organizations ${ }^{(23)}$. 
The labor market increasingly requires professionals able to meet the demands in the context of care integrality and coordination. Therefore, it is essential that nurses undergo updates and training (permanent and continuing education) that complement their training to offer quality assistance, subsidized in evidence-based practice ${ }^{(24)}$.

In this research, nurses recognized themselves as subjects propelling knowledge and lifestyle change, involving the family in this context and signaling that their performance contemplates the attributes of PHC. This reality has been described by similar studies carried out in Brazil and Portugal ${ }^{(25-26)}$.

Among the strategies and tools of diabetes education mentioned, the nursing consultation ${ }^{(27)}$, which is configured as a light-hard care technology, which involves qualified listening and implementation of a systematic and individualized care plan, generating significant improvements in the results of the treatment of chronic patients, as well as reducing their $\operatorname{cost}^{(28)}$. Aiming at the correct management of the patient in the consultation, nurses should seek to instrumentalize themselves routinely through courses and training, although our results have shown a dichotomy between practice and knowledge, a product of the gap in the training and applicability of the nursing processes in daily praxis ${ }^{(22)}$.

Caring for the person living with DM requires clinical knowledge and mastery of effective communication strategies, as well as knowledge of motivating primary care protocols. To that end, the support and investment of managers in continuing education are necessary for the development of the four pillars of PHC: attention in the first contact, logitudinality, completeness, and coordination of care, besides family/community guidance and cultural competence to develop preventive and chronic proactive care based on the needs of the population.

The lack of systematized care, professionals' lack of knowledge about clinical management and the partial (non)compliance with the policies aimed at the person living with DM, as well as the lack of commitment of the nurses to follow the recommended protocols and manuals, are factors that contribute to poor DM control ${ }^{(29)}$. However, the drug delivery policy in the care model developed by the PHC is a strategy that favors compliance to the pharmacological treatment of $\mathrm{DM}^{(30)}$.

The challenges to be overcome constitute a barrier of personal longitudinality in the care to be provided and based on the rethinking of nurse education unrelated to reality, which results in unpreparedness to deal with the problems of the person living with $\mathrm{DM}^{(31)}$. The involvement and development of practices articulated with several health services and actions aimed at the glycemic and metabolic control of DM are considered a real challenge to be overcome.

\section{Limitations of the study}

The limitations of this study are related to the adopted method, which prevents the generalization of the results beyond the subjective context of the participants. The enlargement of the scenarios and the participants will allow offering more subsidies so that the seized meanings are deepened. It is added that the average period of high professional performance can be considered a confounding factor in the participants, influencing the knowledge and the meanings about the subject.

\section{Contributions to the area of nursing and health}

Given the peculiarities that surround the subject in question, the DM has been studied in its pathophysiological aspects lately, highlighting the search for strong evidence that can be used in the clinical practice of the PHC nurse, with contributions focused on health promotion, primary and secondary prevention, treatment and health rehabilitation of individuals and communities, carried out in an interdisciplinary and multidisciplinary way. However, it is relevant to invest in studies that involve the care of the person living with DM in other domains such as training and its meanings for professionals involved in care, especially eSF nurses. Knowing these meanings may be useful for future scientific discussions about the importance of training in the management of self-care in chronic conditions and in the educational practice in health.

\section{CONCLUSION}

The meanings attributed by nurses to diabetes education revealed an insufficient training, too focused on principles of healing subsidized in transmissionist methods, resulting from the limitations imposed by traditional training and the gap between theory and practice. There are few tools available to instrumentalize the education process, limiting the quality of care.

\section{REFERENCES}

1. Flor LS, Campos MR. The prevalence of diabetes mellitus and its associated factors in the Brazilian adult population: evidence from a population-based survey. Rev Bras Epidemiol[Internet]. 2017[cited 2017 Nov 08];20(1):16-29. Available from: http://www. scielo.br/pdf/rbepid/v20n1/en_1980-5497-rbepid-20-01-00016.pdf

2. Guariguata L, Whiting DR, Hambleton I, Beagley J, Linnenkamp U, Shaw JE. Global estimates of diabetes prevalence for 2013 and projections for 2035. Diabetes Res Clin Pract [Internet]. 2014[cited 2017 Nov 08];103(2):137-49. Available from: https://www. ncbi.nlm.nih.gov/pubmed/24630390

3. Fernandes JR, Ogurtsova K, Linnenkamp U, Guariguata L, Seuring T, Zhang P, et al. IDF Diabetes Atlas estimates of 2014 global health expenditures on diabetes. Diabetes Res Clin Pract [Internet]. 2016 [cited 2017 Nov 08];117:48-54. Available from: https:// www.ncbi.nlm.nih.gov/pubmed/27329022

4. Melo LP, Campos EA. "The group facilitates everything": meanings patients with type 2 diabetes mellitus assigned to health education groups. Rev Latino-Am Enfermagem [Internet]. 2014[cited 2017 Nov 08];22(6):980-7. Available from: http://www.scielo.br/pdf/ 
Training in diabetes education: meanings attributed by primary care nurses Coêlho MCVS, Almeida CAPL, Silva ARV, Moura LKB , Feitosa LGGC, Nunes LB.

\section{rlae/v22n6/0104-1169-rlae-22-06-00980.pdf}

5. Brasil. Ministério da Saúde. Departamento de Atenção Básica. Estratégias para o cuidado da pessoa com doença crônica: diabetes mellitus [Internet]. Brasília: Ministério da Saúde, 2013[cited 2017 Nov 08]. Available from: http://bvsms.saude.gov.br/bvs/publicacoes/ estrategias_cuidado_doenca_cronica_diabetes_mellitus.pdf

6. Sociedade Brasileira de Diabetes-SBD. Diretrizes da Sociedade Brasileira de Diabetes: 2013-2014 [Internet]. São Paulo: AC Farmacêutica; 2014[cited 2017 Nov 08]. Available from: http://www.diabetes.org.br/images/pdf/diretrizes-sbd.pdf

7. Canever BP. Produção de conhecimento Latino-Americana sobre educação superior em enfermagem. Health Soc Change[Internet]. 2016[cited 2017 Nov 08];6(2):88-96. Available from: http://incubadora.periodicos.ufsc.br/index.php/saudeetransformacao/article/ view/2708/4473

8. Littejohn SW. Fundamentos teóricos da comunicação humana. Rio de Janeiro: Zahar; 1982.

9. Fernandes JDC. Linguagens: usos e reflexões. 8th ed. Editora UFPB, João Pessoa: 2011.

10. Ogden CK, Richards IA. O significado de significado: um estudo da influência da linguagem sobre o pensamento e sobre a ciência do simbolismo. Rio de Janeiro: Zahar, 1976.

11. Ratinaud P, Marchand P. Application of the ALCESTE method to the large corpus and stabilized lexical worlds or 'cablegate', using IRAMUTEQ. Actes des 11eme JADT. 2012:835-44

12. Jesus GJ, Oliveira LB, Caliari JS, Queiroz AAFLN, Gir E, Reis RK. Difficulties of living with HIV/Aids: Obstacles to quality of life. Acta Paul Enferm[Internet]. 2017[cited 2018 Feb 04];30(3):301-7. Available from: http://www.scielo.br/pdf/ape/v30n3/en_19820194-ape-30-03-0301.pdf

13. Sousa AFL, Queiroz AAFLN, Oliveira LB, Valle ARMC, Moura MEB. Social representations of community-acquired infection by primary care professionals. Acta Paul Enferm[Internet]. 2015[cited 2017 Nov 08];28(5):454-9. Available from: http://dx.doi. org/10.1590/1982-0194201500076

14. Kami MTM, Larocca LM, Chaves MMN, Lowen IMV, Souza VMP, Goto DYN. Working in the street clinic: use of IRAMUTEQ software on the support of qualitative research. Esc Anna Nery Rev Enferm[Internet]. 2016[cited 2017 Nov 08];20(3):e20160069. Available from: http://www.scielo.br/pdf/ean/v20n3/en_1414-8145-ean-20-03-20160069.pdf

15. Queiroz AAFLN, Sousa ÁFL. PrEP Forum: an on-line debate on pre-exposure prophylaxis in Brazil. Cad Saúde Pública[Internet]. 2017[cited 2018 Jan 12];33(11):e00112516. Available from: http://www.scielo.br/pdf/csp/v33n111/1678-4464-csp-33-11-e00112516.pdf

16. Sousa AFL, Queiroz AAFLN, Oliveira LB, Moura MEB, Batista OMA, Andrade D. Social representations of biosecurity in nursing: occupational health and preventive care. Rev Bras Enferm [Internet]. 2016 Oct [cited 2017 Nov 09];69(5):864-71. Available from: http://www.scielo.br/pdf/reben/v69n5/en_0034-7167-reben-69-05-0864.pdf

17. Torres HC, Cortez DN, Reis IA. Avaliação da educação em grupo de diabetes na atenção primária à saúde. Cienc Enferm[Internet]. 2016[cited 2017 Nov 09];22(3):35-45. Available from: https://scielo.conicyt.cl/pdf/cienf/v22n3/0717-9553-cienf-22-03-00035.pdf

18. Yuan X, Wang F, Fish AF, Xue C, Chen T, Liu C, et al. Effect of case management on glycemic control and behavioral outcomes forchinese people with type 2 diabetes: a 2 year study. Patient Educ Couns [Internet]. 2016[cited 2017 Nov 09];99(8):1382-8. Available from: https://www.ncbi.nlm.nih.gov/pubmed/27005564

19. Zhao FF, Suhonen R, Koskinen S, Leino-Kilpi H. Theory-based self-management educational interventions on patients with type 2 diabetes: a systematic review and meta-analysis of randomized controlled trials. J Adv Nurs[Internet]. 2017 [cited 2017 Nov 09];73(4):812-33. Available from: https://www.ncbi.nlm.nih.gov/pubmed/27681948

20. Lopes AAF. Care and Empowerment: the construction of the subject responsible for his own health in the experience of diabetes. Saude Soc[Internet]. 2015[cited 2017 Nov 09];24(2):486-500. Available from: http://www.scielo.br/pdf/sausoc/v24n2/0104-1290sausoc-24-02-00486.pdf

21. Oliveira GYM, Almeida AMO, Girão ALA, Freitas CHA. Nursing interventions for promoting self-care of persons with type 2 diabetes: an integrative review. Rev Eletr Enferm[Internet]. 2016 [cited 2017 Nov 09];18:e1188. Available from: http://pesquisa. bvsalud.org/portal/resource/pt/biblio-832729

22. Ortega MCB, Cecagno D, Llor AMS, Siqueira HCH, Montesinos MJL, Soler LM. Academic training of nursing professionals and its relevance to the workplace. Rev Latino-Am Enfermagem[Internet]. 2015[cited 2017 Nov 09];23(3):404-10. Available from: http:// www.scielo.br/pdf/rlae/v23n3/0104-1169-rlae-23-03-00404.pdf

23. Miccas FL, Batista SHSS. Permanent education in health: a review. Rev Saúde Pública [Internet]. 2014 [cited 2017 Nov 09];48(1):17085. Available from: http://www.scielo.br/pdf/rsp/v48n1/en_0034-8910-rsp-48-01-0170.pdf

24. Poh CL, Parasuram R, Kannusamy P. Nursing inter-shift handover process in mental health settings: a best practice implementation project. Int J Evid Based Healthcare[Internet]. 2013[cited 2017 Nov 09];11(1):26-32. Available from: https://www.ncbi.nlm.nih. gov/pubmed/23448327

25. Souza MB, Rocha PM, Sá AB, Uchoa SAC. Teamwork in primary care: the experience of Portugal . Rev Panam Salud Publica[Internet]. 2013[cited 2017 Nov 09];33(3):190-5. Available from: https://scielosp.org/pdf/rpsp/2013.v33n3/190-195/pt

26. Verchota G, Sawin KJ. Testing components of a self-management theory in adolescents with Type 1 Diabetes Mellitus. Nurs Res[Internet]. 2016 [cited 2017 Nov 09];65(6):487-95. Available from: https://www.ncbi.nlm.nih.gov/pubmed/27801719 
27. Conselho Federal de Enfermagem - COFEn.. Resolução COFEN nº 159/1993 - Revogada pela Resolução Cofen no $0544 / 2017$. Diário Oficial da União [Internet]. Brasília, DF, 2017[cited 2017 Nov 09]. Available from: http://www.cofen.gov.br/resoluocofen-1591993_4241.html

28. Emamifar A, van Bui Hansen $\mathrm{MH}$, Jensen Hansen IM. The ratio of nurse consultation and physician efficiency index of senior rheumatologists is significantly higher than junior physicians in rheumatology residency training: A new efficiency measure in a cohort, exploratory study. Med[Internet] 2017 [cited 2017 Nov 09];96(14):e6601. Available from: https://www.ncbi.nlm.nih.gov/ pmc/articles/PMC5411226/

29. Salci MA, Meirelles BHS, Silva DMGV. Primary care for diabetes mellitus patients from the perspective of the care model for chronic conditions. Rev Latino-Am Enfermagem[Internet]. 2017[cited 2017 Nov 09];25:e2882. Available from: http://www.scielo. br/pdf/rlae/v25/0104-1169-rlae-25-e2882.pdf

30. Gimenes HTF, Santos MA, Arrelias CCA, Rodrigues FFL, Gonela JT, Teixeira CRS, et al. Adherence To Diabetes Mellitus Treatments In Family Health Strategy Units. Rev Esc Enferm USP[Internet]. 2014[cited 2017 Nov 09];48(2):257-63. Available from: http://www. scielo.br/pdf/reeusp/v48n2/0080-6234-reeusp-48-02-257.pdf

31. Oliveira MAC, Pereira IC. Primary Health Care essential attributes and the Family Health Strategy. Rev Bras Enferm[Internet]. 2013[cited 2017 Nov 09];66(spe):158-64. Available from: http://www.scielo.br/pdf/reben/v66nspe/v66nspea20.pdf 